\title{
Organic acids in diets of weaned piglets: performance, digestibility and economical viability
}

[Ácidos orgânicos em dietas para leitões desmamados: desempenho, digestibilidade e viabilidade econômica]

\author{
A.D.C.V. Boas ${ }^{1}$, F.E.L. Budiño ${ }^{2 *}$, M.A.T. Neto $^{3}$, A. Schmidt ${ }^{1}$, J.C. Dadalt ${ }^{3}$, R.P. Monferdini ${ }^{1}$, \\ N.Y. Sitanaka ${ }^{1}$, J.E. Moraes ${ }^{2}$, C.C. Pizzolante ${ }^{2}$ \\ ${ }^{1}$ Aluno de pós-graduação - Instituto de Zootecnia - Secretaria de Agricultura e Abastecimento \\ do Estado de São Paulo - Nova Odessa, SP \\ ${ }^{2}$ Instituto de Zootecnia - Secretaria de Agricultura e Abastecimento do Estado de São Paulo - Nova Odessa, SP \\ ${ }^{3}$ Faculdade de Medicina Veterinária e Zootecnia - Universidade de São Paulo - São Paulo, SP
}

\begin{abstract}
Organic acids are used as feed additives to promote growth of weaned piglets since they prevent the occurrence of diarrhea. Thus, performance and digestibility assays were conducted and economic viability of diets was evaluated. In the performance assays, 64 hybrid piglets weaned with a mean weight of $5.87 \pm 0.31 \mathrm{~kg}$ were divided in a randomized block design consisting of 4 treatments, 8 repetitions and 2 piglets per experimental unit ( 1 castrated male and 1 female). In the digestibility assay, 24 castrated male hybrid piglets with a mean weight of $8.21 \pm 0.79 \mathrm{~kg}$ were individually assigned to 4 treatments and 6 repetitions. The treatments in the two assays were as follows: control, basal diet without addition of an acidifier; blend: inclusion of $0.5 \%$ of a mixture of organic acids; butyrate: inclusion of $0.1 \%$ of sodium butyrate; blend+butyrate: inclusion of $0.5 \%$ of a mixture of organic acids and $0.1 \%$ sodium butyrate. There was no effect $(\mathrm{P}>0.05)$ of the acidifiers on animal performance during the period studied. Organic acids exerted no effect $(\mathrm{P}>0.05)$ on the apparent digestibility coefficients of nutrients. Diets supplemented with sodium butyrate had an economic advantage for the period of 10-24 days. No episode of diarrhea was observed. This study demonstrated no effect of acidifier feed additives as growth promoters in complex diets for weaned piglets.
\end{abstract}

Keywords: acidifiers, additives, digestibility, performance, pigs

\section{RESUMO}

Ácidos orgânicos são utilizados como aditivos promotores de desempenho em leitões, pois podem prevenir a ocorrência de diarreias. Para tanto, foram conduzidos ensaios de desempenho, digestibilidade, e foi avaliada a viabilidade econômica das dietas. No desempenho, foram utilizados 64 leitões híbridos desmamados, com peso médio de $5,87 \pm 0,31 \mathrm{~kg}$, distribuídos em um delineamento em blocos ao acaso, com quatro tratamentos, oito repetições e dois leitões por unidade experimental (sendo um macho castrado e uma fêmea). Na digestibilidade, 24 leitões machos, castrados, híbridos, com peso médio de $8,21 \pm 0.79 \mathrm{~kg}$, foram alojados individualmente em quatro tratamentos e seis repetições. Em ambos os ensaios, os tratamentos foram: controle: dieta basal sem uso de acidificante; Blend: inclusão de $0,5 \%$ da mistura de ácidos orgânicos; butirato: inclusão de 0,1\% de butirato de sódio; Blend+Butirato: inclusão de 0,5\% da mistura de ácidos orgânicos e 0,1\% butirato de sódio. Não houve efeito dos acidificantes $(P>0,05)$ sobre o desempenho no período estudado. Não houve efeito dos ácidos orgânicos $(P>0,05)$ sobre os coeficientes de digestibilidade aparente dos nutrientes. Dietas com suplementação de butirato de sódio apresentaram melhor vantagem econômica para o período de 10-24 dias. Não houve incidência de diarreia em nenhum período. Não ficou evidenciado o efeito dos aditivos acidificantes como promotores de crescimento em dietas complexas para leitões desmamados.

Palavras-chave: acidificantes, aditivos, digestibilidade, desempenho, suínos

Recebido em 09 de junho de 2015

Aceito em 15 de novembro de 2015

*Autor para correspondência (corresponding author)

E-mail: fbudino@iz.sp.gov.br 


\section{INTRODUCTION}

The global production of pork has increased substantially in recent decades as a result of the growing demand for animal protein. In the end of 2014, the world production was $110,606(1,000$ MT), with China leading the market, followed by the European Union, United States, and Brazil (ABPA, 2015).

Piglets are commonly weaned between 21 and 28 days of age. However, this phase, as well as subsequent days, is a critical period for animal development because of the stress caused by separation from the mother, formation of new batches and changes in the type of food and diet composition, associated with immaturity of the digestive system and drastic changes in the intestinal physiology of piglets (Corassa et al., 2006; Silva et al., 2008; Kumer et al., 2009). The $\mathrm{pH}$ of the digestive tract of piglets is high at this stage and the production of hydrochloric acid and digestive enzymes is insufficient (Tsiloyiannis et al., 2001). Digestion is further compromised by the administration of complex diets with a high protein content (Chiquieri, 2009), a fact favoring the proliferation of pathogenic microorganisms and development of intestinal disorders (Viola and Vieira, 2007; Bocklor et al., 2007). All of these factors contribute to the occurrence of post-weaning diarrhea, which can lead to the death of the animal or significant weight loss during subsequent phases (Corassa et al., 2006; Sanches et al., 2006).

Previous studies suggest that the development of pathogens in recently weaned piglets can be controlled by the use of feed additives such as organic acids and their salts, especially during the first two weeks after weaning (Partanen and Mroz, 1999; Freitas et al., 2006; Bocklor et al., 2007). Despite different action mechanisms, short-chain organic acids such as formic, citric, lactic, acetic and propionic acid can reduce the growth of microorganisms by exerting a specific antimicrobial effect or by reducing gastric $\mathrm{pH}$ (Partanen and Mroz, 1999; Biagi et al., 2007). Moreover, these acids have multifunctional properties that can affect different performance parameters. For example, in addition to modulating the gastrointestinal microbiota, butyric acid or sodium butyrate is the preferential energy source for intestinal cells and plays an important regulatory function in cell proliferation, cell differentiation, and apoptosis inhibition (Biagi et al., 2007; Claus et al., 2008; Mazzoni et al., 2008; Machinsky et al., 2010).

However, the results of studies evaluating the effect of adding organic acids to weaned piglet diets are still controversial (Zentek et al., 2013). Some studies observed improvement in performance and diet digestibility, with a consequent reduction in gastrointestinal disorders (Chiquieri et al., 2009; Machinsky et al., 2010; Braz et al., 2011), while others found no effects on these parameters (Freitas et al., 2006; Rego et al., 2012). It is still not possible to establish whether these variations are the result of differences in diet composition (Freitas et al., 2006) and in the types of acid tested, their concentrations and specific combinations (blend), or are due to synergism and/or antagonism between ingredients and these additives that could mask possible effects. Therefore, further studies are needed to establish the specific conditions in which these additives are effective.

In this study, the effect of supplementation of complex diets with organic acids on the performance of weaned piglets and nutrient digestibility, as well as its economic viability was evaluated. For this purpose, the effect of the inclusion of a mixture of lactic, formic and citric acid, combined or not with sodium butyrate was investigated.

\section{MATERIAL AND METHODS}

The present study was approved by the animal welfare committee of the Institute of Animal Science, São Paulo, Brazil (Certificate number 151).

The performance and digestibility experiments were conducted at the Pig Farming Sector of the Institute of Animal Science, Nova Odessa, São Paulo, Brazil.

Sixty-four hybrid piglets weaned at 21 days of age and weighing on average $5.87 \pm 0.31 \mathrm{~kg}$ were used. The animals were divided in a randomized block design consisting of four treatments and eight repetitions. Body weight and sex of pigs were used as criteria in the block formation. The pen where two animals were housed (one castrated male and one female) served as the experimental unit. 
Four treatments were studied: T1 (control): basal diet without the addition of an acidifier; $\mathrm{T} 2$ (blend): inclusion of $0.5 \%$ of a mixture of organic acids; T3 (butyrate): inclusion of $0.1 \%$ of sodium butyrate; T4 (blend+butyrate): inclusion of $0.5 \%$ of a mixture of organic acids and $0.1 \%$ sodium butyrate. In T2, T3 and T4, kaolin was replaced with the respective acidifiers. The mixture of organic acids (blend) consisted of $21 \%$ lactic acid, $18 \%$ formic acid, and $10 \%$ citric acid. Microencapsulated sodium butyrate at a concentration of $30 \%$ was used.
The diets were fed to the piglets from 21 to 66 days of age, divided into three periods: pre-initial I ( 0 to 10 days postweaning), pre-initial II (10 to 24 days), and initial (24 to 45 days). The diets were formulated to meet the nutritional requirements of piglets during the nursery phase according to Rostagno et al. (2011). Analyses of the diets $(\mathrm{CP}$, crude fiber, ether extract, ash, and starch) were performed according to AOAC (1975) standard methods at the Animal Science Institute, Nova Odessa, Sao Paulo State. Water and ration were available ad libitum. Tab. 1 shows the percent composition of the diets.

Table 1. Percent composition of the pre-initial I diet (0 to 10 days), pre-initial II diet (10 to 24 days) and initial diet (24 to 45 days)

\begin{tabular}{|c|c|c|c|}
\hline Ingredients & Pre-initial I & Pre-initial II & Initial \\
\hline Corn grain $7.5 \%$ & 33.21 & 50.90 & 61.16 \\
\hline Soybean meal 46\% & 20.00 & 24.00 & 30.00 \\
\hline Kaolin & 0.60 & 0.60 & 0.60 \\
\hline Gelatinized rice flour & 10.00 & 0.00 & 0.00 \\
\hline Blood plasma & 2.00 & 1.50 & 0.00 \\
\hline Soybean oil & 1.20 & 1.50 & 2.00 \\
\hline Whole milk powder & 10.00 & 0.00 & 0.00 \\
\hline Sugar & 4.00 & 5.00 & 3.00 \\
\hline Whey & 16.00 & 13.50 & 0.00 \\
\hline Dicalcium phosphate & 0.90 & 1.40 & 1.50 \\
\hline Limestone & 0.00 & 0.00 & 0.70 \\
\hline Salt & 0.00 & 0.05 & 0.50 \\
\hline DL-methionine & 0.31 & 0.25 & 0.00 \\
\hline L-lysin 78\% & 0.50 & 0.67 & 0.20 \\
\hline L-tryptophane $98 \%$ & 0.025 & 0.023 & 0.000 \\
\hline L-threonine 98\% & 0.20 & 0.20 & 0.00 \\
\hline Choline chloride $60 \%$ & 0.05 & 0.05 & 0.05 \\
\hline Colistin 80 & 0.05 & 0.05 & 0.05 \\
\hline Antioxidant ${ }^{(1)}$ & 0.01 & 0.01 & 0.01 \\
\hline Flavoring agent ${ }^{(2)}$ & 0.025 & 0.025 & 0.000 \\
\hline Palatability agent ${ }^{(3)}$ & 0.05 & 0.05 & 0.02 \\
\hline Copper sulfate $35 \%$ & 0.075 & 0.030 & 0.040 \\
\hline Vitamin supplement ${ }^{(4)}$ & 0.10 & 0.10 & 0.08 \\
\hline Mineral supplement ${ }^{(4)}$ & 0.10 & 0.10 & 0.09 \\
\hline Total & 100.00 & 100.00 & 100.00 \\
\hline \multicolumn{4}{|c|}{ Calculated Nutritional Composition } \\
\hline $\mathrm{ME}(\mathrm{Mcal} / \mathrm{kg})$ & 34.33 & 33.25 & 32.84 \\
\hline Crude protein $(\%)$ & 18.14 & 17.61 & 18.62 \\
\hline Lactose $(\%)$ & 16.05 & 10.12 & 5.00 \\
\hline Calcium (\%) & 0.47 & 0.52 & 0.70 \\
\hline Total phosphorus (\%) & 0.78 & 0.67 & 0.59 \\
\hline Digestible lysin (\%) & 1.34 & 1.31 & 0.99 \\
\hline Digestible methionine (\%) & 0.56 & 0.47 & 0.26 \\
\hline Digestible tryptophane $(\%)$ & 0.22 & 0.20 & 0.19 \\
\hline Digestible threonine (\%) & 0.79 & 0.74 & 0.59 \\
\hline
\end{tabular}

(1) Endox 5X commercial product; (2) Cream Sicle commercial product; (3) Power Sweet commercial product; (4) nutritional levels per kg ration: vitamin $\mathrm{A}-10,000 \mathrm{IU}$; vitamin $\mathrm{D}_{3}-1,650 \mathrm{IU}$; vitamin $\mathrm{E} 60 \mathrm{mg} / \mathrm{kg}$; vitamin $\mathrm{K}-20 \mathrm{mg}$; vitamin B1 - 1.19mg; vitamin B2 - 4mg; vitamin B6 - 2.19mg; vitamin B12 - 22 $\mu \mathrm{g}$; folic acid - 0.39mg; pantothenic acid - 18mg; biotin - 0.15mg; niacin - 29.84mg; choline - 1113.74mg; copper - 273.10mg; iron - 90mg; iodine $-1.10 \mathrm{mg}$; manganese $-40.2 \mathrm{mg}$; selenium $-0.36 \mathrm{mg}$; zinc $-117.8 \mathrm{mg}$. 
The following performance variables were evaluated: daily feed intake, average daily gain, and feed conversion. The animals were weighed at the beginning and at the end of each period studied, corresponding to days 1, 10, 24 and 45 of the experiment. Leftover and wasted feed were weighed weekly for the determination of feed intake.

Twenty-four hybrid piglets with an initial mean weight of $8.21 \pm 0.79 \mathrm{~kg}$ were used for digestibility evaluation. The experimental design consisted of random blocks with four treatments and six repetitions. The animals were housed in metabolic cages similar to the model suggested by Pekas (1968).

The animals were adapted for 10 days prior to assessment. The assays were performed consecutively using the same animals for the three assays. The animals remained in the same treatment since the initial allocation before adaptation.

The diets used in the digestibility experiment had the same formulation as those used in the performance assay (pre-initial I, pre-initial II, and initial diet) and the diet composition and nutritional value are shown in Tab. 1. The total fecal collection method was used, adding 1.5\% of ferric oxide $\left(\mathrm{Fe}_{2} \mathrm{O}_{3}\right)$ as a marker to the diets. The beginning and end of the collection period were determined by the occurrence of stained feces. Urine was collected daily and the samples were frozen until the time of laboratory analysis. The nitrogen analyses of feces and urine were performed according to AOAC (1975), at the Department of Animal Nutrition and Production, FMVZ - University of São Paulo.

Economic viability was evaluated for the preinitial I (0-10 days), pre-initial II (10-24 days) and initial (24-45 days) periods and for the total period (0 to 45 days). First, feed cost per kilogram live weight gain (in $\mathrm{R} \$$ ) was determined. Next, the economic efficiency index (EEI) was calculated as suggested by Bellaver et al. (1985), apud Tavernari et al. (2009), as follows:

$$
\mathrm{Y}_{\mathrm{i}}=\left(\mathrm{P}_{\mathrm{i}} * \mathrm{Q}_{\mathrm{i}}\right) / \mathrm{G}_{\mathrm{i}}
$$

where $Y_{\mathrm{i}}$ is feed cost per kilogram live weight gain in the $i^{\text {th }}$ treatment; $P_{\mathrm{i}}$ is the price per kilogram feed used in the $i^{\text {th }}$ treatment; $Q_{\mathrm{i}}$ is the amount of feed consumed in the $i^{\text {th }}$ treatment, and $G_{\mathrm{i}}$ is the weight gain in the $i^{\text {th }}$ treatment. The EEI was then calculated as follows:

$$
\mathrm{EEI}=(\mathrm{MCe} / \mathrm{CTei}) * 100
$$

where $M C e$ is the lowest feed cost per kilogram gain observed in the treatments; $C T e_{i}$ is the cost of treatment $i$ considered.

The costs of the ingredients used for the elaboration of the diets were based on the prices valid in São Paulo on August 13, 2013.

The data of the performance and digestibility experiments were analyzed using the PROC GLM module (General Linear Models) of the SAS program (Statistical Analysis System, 2001).

\section{RESULTS AND DISCUSSION}

Daily feed intake, average daily gain or feed conversion did not differ significantly $(\mathrm{P}>0.05)$ between treatments during the three periods studied (0-10, 0-24 and 0-45 days) (Tab. 2).

These results are consistent with those reported in a previous study (Gomes et al. 2007) that evaluated the performance of piglets from 15 to 36 days of age supplemented with fumaric acid combined or not with butyric and formic acid which performance parameters was not affected by treatments. A study evaluating the effect of a growing proportion of mixtures of organic acids based on lactic acid also found no significant differences in daily feed intake or average daily gain (Freitas et al., 2006). On the other hand, the inclusion of different levels of fumaric acid in the diet (Miguel et al., 2011), as well as the use of different combinations of formic acid, lactic acid, propionic acid and sodium butyrate (Braz et al., 2011), significantly improved different performance parameters, including average daily gain, in post weaning piglets. 
Organic acids in diets...

Table 2. Initial and final live weight, daily feed intake (DFI), average daily gain (ADG) and feed conversion (FC) of weaned piglets from 1 to 45 days of the experiment

\begin{tabular}{ccccccc}
\hline & Control $^{1}$ & Blend $^{1}$ & Butyrate $^{1}$ & ${\text { Blend + } \text { butyrate }^{1}}$ & CV (\%) & P value $^{2}$ \\
\hline Body weight (kg) & & & & & & \\
Initial & 5.86 & 5.86 & 5.87 & 5.87 & 0.10 & 0.926 \\
Final & 27.71 & 28.90 & 28.93 & 29.75 & 2.91 & 0.3739 \\
0 - 10 days & & & & & & \\
DFI (g) & 516 & 539 & 530 & 592 & 6.08 & 0.4253 \\
ADG (g) & 389 & 407 & 386 & 454 & 7.69 & 0.3291 \\
FC & 1.34 & 1.35 & 1.40 & 1.32 & 2.46 & 0.8607 \\
0 - 24 days & & & & & & \\
DFI (g) & 971 & 1037 & 992 & 1113 & 6.12 & 0.1526 \\
ADG (g) & 675 & 718 & 728 & 794 & 6.79 & 0.0893 \\
FC & 1.44 & 1.45 & 1.37 & 1.40 & 2.67 & 0.3919 \\
0 - 45 days & & & & & & \\
DFI (g) & 1619 & 1728 & 1695 & 1755 & 3.46 & 0.4002 \\
ADG (g) & 971 & 1024 & 1024 & 1061 & 3.64 & 0.2805 \\
FC & 1.68 & 1.69 & 1.65 & 1.66 & 0.99 & 0.9088 \\
\hline
\end{tabular}

${ }^{1}$ Lack of effect between treatments by the Tukey test $(\mathrm{P}>0.05) .{ }^{2} \mathrm{CV}(\%)$ : coefficient of variation.

The absence of differences between treatments may be due to the presence of relatively high levels of dicalcium phosphate and limestone in the diet of piglets. Sources such as dicalcium phosphate and limestone possess a high buffering capacity (Levic, 2005) which often confers a high basic $\mathrm{pH}$ to the piglet's intestinal content, a fact that may have masked the effect of organic acids in the diets tested. In fact, high buffering capacities were obtained with dicalcium phosphate and a vitamin/mineral mixture in complex diets used for piglets (Bockor et al., 2007).

The lack of effect of the experimental diets may also be associated with the use of milk ingredients such as whole milk powder and whey at inclusion levels of $10.0 \%$ to $16.6 \%$ in order to meet the minimum lactose levels. In weaning piglets, lactose derived from milk products is converted into lactic acid, producing desirable changes in gastric development (Bockor et al., 2007). However, the presence of milk products can reduce the efficacy of acidifiers because of their palatability and fermentation effect and consequent acidification of the gastrointestinal tract (Silva et al., 2008). This would explain the observation that the use of organic acids is more effective in the case of simple cereal-soybean meal-based diets compared to more complex diets that contain milk ingredients or animal origin proteins (Partanen and Mroz, 1999).
An important characteristic of the tested diets is that all of them contained the antimicrobial additive colistin. This is a common practice on Brazilian factory farms which use a type of growth promoter. In general, the use of antibiotics in diets increases the growth rate, improves feed conversion and reduces mortality due to infections, especially by moderately controlling pathogenic microorganisms that colonize the gastrointestinal tract (Lovatto et al., 2005). These features possibly contributed to maintain animal health and reduced the effect of the acidifiers in the treatments evaluated.

In the present study, no episodes of diarrhea were observed in the piglets over the experimental period. In addition to the fact that the assays were conducted in an experimental farm environment with adequate cleaning standards, the presence of zinc oxide (Arantes et al., 2007), copper sulfate (Rutz and Lima, 2001) and colistin (Lovatto et al., 2005) in the diets may have inhibited the growth of microorganisms in the gastrointestinal tract. Several authors suggested that the challenges imposed by the rearing environment, variations in environmental conditions and stressors associated with animal management favor the action of organic acids and potentiate their effects (Silva et al., 2008). Hence, the decreased challenge during the assays may have reduced the expression of the characteristics of organic acids related to animal performance. 
Finally, the lack of differences in piglet performance between treatments may be attributed to the use of a complex diet (Kiefer and Quadros, 2006). Acidifiers are more effective in improving the performance of weaned piglets when added to simple diets based on cereals and soybean meal compared to complex diets containing milk products (Miguel et al., 2011) and animal origin protein (Silva et al., 2008).

Tab. 3 shows the digestibility coefficients and energy content of the pre-initial I, pre-initial II and initial diets. No significant differences $(\mathrm{P}>0.05)$ were observed between treatments, i.e., supplementation with organic acids in the form of blend, sodium butyrate or the combination of the two products did not influence apparent fecal digestibility of dry matter, crude protein, gross energy or digestible and metabolizable energy. These results are consistent with previous studies that found no effects of supplementation of piglet diets with fumaric acid (Miguel et al., 2011) or sodium butyrate combined with phytogenic compounds on digestibility parameters. In a study in which the use of butyric acid influenced crude protein digestibility (Mackinsky et al., 2010), the diet used was simple (no addition of milk products) and the animals were already in the beginning of the growth phase.

Table 3. Apparent digestibility coefficients of dry matter (DCDM) and crude protein (DCCP), nitrogen retention coefficient (NRC), digestible energy (DE) and metabolizable energy (ME) of the pre-initial I, pre-initial II and initial diets fed to weaned piglets

\begin{tabular}{|c|c|c|c|c|c|c|}
\hline Variable & Control $^{1}$ & Blend $^{1}$ & Butyrate $^{1}$ & Blend + butyrate $^{1}$ & $\mathrm{CV}^{2}{ }^{2}$ & $P$ value \\
\hline \multicolumn{7}{|c|}{ Pre-initial I phase } \\
\hline DCDM $(\%)$ & 91.91 & 92.00 & 92.13 & 92.86 & 0.46 & 0.5855 \\
\hline $\operatorname{DCCP}(\%)$ & 89.37 & 87.07 & 88.8 & 89.15 & 1.17 & 0.2246 \\
\hline NRC (\%) & 80.99 & 78.51 & 80.55 & 80.07 & 1.35 & 0.2485 \\
\hline DE (kcal/kg) & 3596 & 3591 & 3604 & 3622 & 0.38 & 0.7583 \\
\hline $\mathrm{ME}(\mathrm{kcal} / \mathrm{kg})$ & 3527 & 3529 & 3546 & 3563 & 0.47 & 0.7011 \\
\hline \multicolumn{7}{|c|}{ Pre-initial II phase } \\
\hline $\operatorname{DCDM}(\%)$ & 91.19 & 90.60 & 91.30 & 90.74 & 0.37 & 0.8917 \\
\hline $\operatorname{DCCP}(\%)$ & 89.51 & 86.81 & 88.15 & 87.06 & 1.40 & 0.3937 \\
\hline NRC (\%) & 83.81 & 80.86 & 81.31 & 81.39 & 1.62 & 0.3887 \\
\hline DE (kcal/kg) & 3570 & 3531 & 3570 & 3546 & 0.53 & 0.7708 \\
\hline $\mathrm{ME}(\mathrm{kcal} / \mathrm{kg})$ & 3523 & 3493 & 3525 & 3512 & 0.41 & 0.8890 \\
\hline \multicolumn{7}{|l|}{ Initial phase } \\
\hline DCDM $(\%)$ & 89.67 & 89.55 & 89.97 & 89.89 & 0.21 & 0.9742 \\
\hline $\operatorname{DCCP}(\%)$ & 87.58 & 86.83 & 88.05 & 88.00 & 0.64 & 0.7759 \\
\hline NRC (\%) & 71.5 & 72.82 & 72.6 & 73.13 & 0.97 & 0.824 \\
\hline $\mathrm{DE}(\mathrm{kcal} / \mathrm{kg})$ & 3515 & 3506 & 3524 & 3518 & 0.21 & 0.9786 \\
\hline $\mathrm{ME}(\mathrm{kcal} / \mathrm{kg})$ & 3442 & 3449 & 3469 & 3457 & 0.33 & 0.8977 \\
\hline
\end{tabular}

${ }^{1}$ Lack of effect between treatments by the Tukey test $(\mathrm{P}>0.05) .{ }^{2} \mathrm{CV}(\%)$ : coefficient of variation.

Analysis of economic viability (Tab. 4) showed that the control diet was the most efficient, and consequently the least expensive, during all phases, except for the pre-initial II period (10 to 24 days) when treatment with sodium butyrate was more efficient, showing lower cost per kilogram weight gain and EEI. Since the pre- initial II phase only comprises 14 days of the total period (45 days) and all diets including acidifiers were more expensive, our results suggest that the inclusion of acidifiers in complex diets such as those used in the present study is economically unviable. 
Organic acids in diets...

Table 4. Cost per kilogram feed ( $\mathrm{R} \$ / \mathrm{kg}$ ration), feed cost per kilogram live weight gain $(\mathrm{R} \$ / \mathrm{kg} \mathrm{WG})$ and economic efficiency index (EEI) obtained for the different phases and for the total period of the experiment

\begin{tabular}{|c|c|c|c|c|}
\hline Phase & Control & Blend & Butyrate & Blend + butyrate \\
\hline \multicolumn{5}{|c|}{ Pre-initial I (0 to 10 days) } \\
\hline $\mathrm{R} \$ / \mathrm{kg}$ feed & 1.7820 & 1.8471 & 1.8018 & 1.8670 \\
\hline $\mathrm{R} \$ / \mathrm{kg} W G$ & 2.3604 & 2.4480 & 2.4728 & 2.4307 \\
\hline $\mathrm{EEI} \%$ & 100.00 & 96.42 & 95.45 & 97.10 \\
\hline \multicolumn{5}{|c|}{ Pre-initial II (10 to 24 days) } \\
\hline $\mathrm{R} \$ / \mathrm{kg}$ feed & 1.2547 & 1.3199 & 1.2746 & 1.3397 \\
\hline $\mathrm{R} \$ / \mathrm{kg} W G$ & 1.8508 & 1.9541 & 1.7338 & 1.9183 \\
\hline EEI\% & 93.68 & 88.72 & 100.00 & 90.38 \\
\hline \multicolumn{5}{|c|}{ Initial (24 to 45 days) } \\
\hline $\mathrm{R} \$ / \mathrm{kg}$ feed & 0.7093 & 0.7745 & 0.7292 & 0.7943 \\
\hline $\mathrm{R} \$ / \mathrm{kg} W G$ & 1.2784 & 1.4186 & 1.3360 & 1.4476 \\
\hline EEI\% & 100.00 & 90.11 & 95.69 & 88.31 \\
\hline \multicolumn{5}{|c|}{ Total (0 to 45 days) } \\
\hline $\mathrm{R} \$ / \mathrm{kg}$ ration & 1.1174 & 1.1825 & 1.1372 & 1.2024 \\
\hline $\mathrm{R} \$ / \mathrm{kg} W G$ & 1.8633 & 1.9945 & 1.8815 & 1.9889 \\
\hline EEI\% & 100.00 & 93.42 & 99.03 & 93.69 \\
\hline
\end{tabular}

Calculated based on the price of the raw materials on August 13, 2013.

\section{CONCLUSION}

Our results suggest that, under the conditions studied, the addition of acidifiers (blend and sodium butyrate) as growth promoters to highly digestible complex diets does not alter the performance or nutrient digestibility of piglets during the nursing phase. Considering the cost of these ingredients, their use is not recommended under these conditions.

\section{ACKNOWLEDGEMENTS}

We thank Coordenação de Aperfeiçoamento de Pessoal de Nível Superior (CAPES) for the fellowship granted to Andréia Donizeti Chagas Vilas Boas.

\section{REFERENCES}

ASSOCIAÇÃO BRASILEIRA DE PROTEÍNA ANIMAL. Relatorio anual, 2015. São Paulo: ABPA, 2015. Available from: <http://abpabr.com.br/setores/suinocultura/publicacoes/relatoriosanuais $>$. Accessed in: october, 15th. 2015.
ARANTES, V.M.; THOMAZ, M.C.; KRONKA, R.N. et al. Níveis de zinco na dieta de leitões recémdesmamados sobre o perfil de parâmetros sangüíneos. Ciênc. Anim. Bras., v.8, p.193-205, 2007.

BELlAVER, C.; FIALHO, E.T.; PROTAS, J.F.S. et al. Radícula de malte na alimentação de suínos em crescimento e terminação. Pesqui. Agropecu. Bras., v.20, p.969-974, 1985.

BIAGI, G.; PIVA, A.; MOSCHINI, M. et al. Performance, intestinal microflora, and wall morphology of weanling pigs fed sodium butyrate. $J$. Anim. Sci., v.85, p.114-119, 2007.

BOCKOR, L.; DAHLKE, F.; MAIORKA, A. et al. Comparação de medidas da capacidade tamponante de matérias-primas e dietas utilizadas para leitões. Arch. Vet. Sci., v.12, p.1-76, 2007.

BRAZ, D.B.; COSTA, L.B.; BERENCHTEIN, B. et al. Acidificantes como alternativas aos antimicrobianos promotores de crescimento de leitões. Arch. Zootec., v.60. p.745-756, 2011.

CHIQUIERI, J.; SOARES, R.T.R.N.; LYRA, M.S. et al. Ácidos orgânicos na alimentação de leitões desmamados. Arch. Zootec., v.58, p.609-612, 2009. 
CLAUS, R.; GUNTHNER, D.; LETZGUSS, H. Effects of feeding fat-coated butyrate on mucosal morphology and function in the small intestine of the pig. J. Anim. Physiol. Anim. Nutr., v.91, p. 312-318, 2008.

CORASSA, A.; DARCI, C.L.; OSTERMANN, J.D. et al. Níveis de ácido fólico em dietas contendo ácido fórmico para leitões de 21 a 48 dias de idade. Rev. Bras. Zootec., v.35, p.462-470, 2006.

FREITAS, L.S.; LOPES, D.C.; FREITAS, A.F. et al. Avaliação de ácidos orgânicos em dietas para leitões de 21 a 49 dias de idade. Rev. Bras. Zootec., v.35, p. 1711-1719, 2006.

GOMES, F.E.; FONTES, D.O.; SALIBA, E.O.S. et al. Ácido fumárico e sua combinação com os ácidos butírico ou fórmico em dietas de leitões recém desmamados. Arq. Bras. Med. Vet. Zootec., v.59, p.1270-1277, 2007.

KIEFER, C.; QUADROS, A.R.B. Efeito da acidificação de dietas simples e complexas sobre o desempenho de leitões nas fases iniciais de crescimento. Rev. Ceres, v.53, p.179-187, 2006.

KUMMER, R.; GONÇALVES, M.A.D.; LIPPKE, R.T. et al. Fatores que influenciam o desempenho dos leitões na fase de creche. Acta Sci. Vet., v.37, p.195209, 2009.

LEVIC, J. Understending the buffering capacity feedstuffs. Biotechnol. Anim. Husb., v.21, p.309-313, 2005.

LOVATTO, P.A.; OLIVEIRA, V.; HAUPTLI, L. et al. Alimentação de leitões na creche com dietas sem aditivos antimicrobianos, com alho (Allium sativum, L.) ou colistina. Cienc. Rural, v.35, p.656-659, 2005

MACHINSKY, T.G.; KESSLER, A.M.; RIBEIRO, A.M.L. et al. Digestibilidade de nutrientes e balanço de $\mathrm{Ca}$ e $\mathrm{P}$ em suínos recebendo dietas com ácido butírico, fitase e diferentes níveis de cálcio. Ciênc Rural., v.40, p. 2350-2355, 2010.

MAZZONI, M.; GALL, M.L.; FILIPPI, S. et al. Supplemental sodium butyrate stimulates different gastric cells in weaned pigs. J. Nutr., v.138, p.14261431,2008

MIGUEL, W.C.; TRINDADE NETO, M.A.; BERTO, D.A. et al. Suplementação de acidificantes em rações de leitões desmamados: desempenho e digestibilidade. Braz. J. Vet. Res. Anim. Sci., v.48, p.141-146, 2011.

OFFICIAL methods of analysis. 12. ed. Washington: Willian Horwitz, 1975. 1094 p.
PARTANEN, K.H.; MROZ, Z. Organic acids for performance enhacement in pig diets. Nutr. Res. Rev., v.12, p.117-145, 1999.

PEKAS, J.C. Versatile swine laboratory apparatus for physiologic and metabolic studies. J. Anim. Sci., v.27, p.1303-130, 1968.

REGO, J.C.C.; FERREIRA, R.A.S.; BRITO, C.F. et al. Acidificação da dieta ea digestibilidade de nutrientes em leitões. Rev. Acad. Ciênc. Agrár. Ambient., v.10, p.105-111, 2012.

ROSTAGNO, H.S.; ALBINO, L.F.T.; DONZELE, J.L. et al. Tabelas brasileiras para aves e suínos: composição de alimentos e exigências nutricionais. Viçosa: UFV, 2011. 252 p.

RUTZ, F.; LIMA, G.J.M.M. O uso de antimicrobianos como promotores de crescimento no Brasil. In: CONGRESSO BRASILEIRO DE VETERINÁRIOS ESPECIALISTAS EM SUÍNOS, 2001, Porto Alegre, RS. Anais... Concórdia, SC: CNPSA, 2001. 10p. CDROM.

SANCHES, A.L.; LIMA, J.A.F.; FIALHO, E.T. et al. Utilização de probiotico, prebiotico e simbiótico em rações de leitões ao desmame. Ciênc. Agrotec., v.30, p.774-777, 2006.

SAS: language reference. Version 8, Cary: SAS2001. 1042p.

SILVA, A.M.R.; BERTO, D.A.; LIMA, G.J.M. et al.. Valor nutricional e viabilidade econômica de rações suplementadas com maltodextrina e acidificante para leitões desmamados. Rev. Bra.s Zootec., v.37, p. 286295, 2008.

TAVERNARI, F.C.; DUTRA, JUNIOR, W.M.; ALBINO, L.F.T. et al. Efeito da utilização de farelo de girassol na dieta sobre o desempenho de frangos de corte. Rev. Bras. Zootec., v.38, p.1745-1750, 2009.

TSILOYIANNIS, V.K.; KYRIAKIS, S.C.; VLEMMAS, J. et al. The effect of organic acids on the control of porcine post-weding diarrhea. Res. Vet. Sci., v.70, p.287-293, 2001.

VIOLA, E.S.; VIEIRA, S.L. Suplementação de acidificantes orgânicos e inorgânicos em dietas para frangos de corte: desempenho zootécnico e morfologia intestinal. Rev. Bras. Zootec., v.36, p.1097-1104, 2007.

ZENTEK, J.; FERRARA, F.; PIEPER, R. et al. Effects of dietary combinations of organic acids and medium chain fatty on the gastrointestinal microbial ecology and bacterial metabolites in the digestive tract of weaning piglets. J. Anim. Sci., v.91, p.3200-3210, 2013. 